\title{
SOME POLITICAL ASPECTS OF IMMIGRATION
}

\author{
Lawrence H. Fuchs*
}

The understanding of American politics rests upon two facts of American life: ideological unity and group pluralism. The purpose of this article will be to show the extent to which the historic American policy of welcoming immigrants has shaped the pluralistic character of American politics and briefly to explore contemporary developments and the implied changes which will be wrought by the present restrictive immigration policy. The impact of the immigration issue on voting behavior and the party system has, with some exceptions, not been large; but the political consequences of immigration itself have been deep and continuing. While each immigrant group, in its turn, has been quick to acquiesce in the basic tenets of the American creed, each has brought into the contest for political power its own brand or style of politics, and, more importantly, its own particular group claims. The very fact of ideological unity in the European sense has heightened the cohesiveness of nationality and ethnic-group expression in the maelstrom of American politics.

Immigrant Groups and the Development of the American Party System ${ }^{1}$

Soon after the writing of the Constitution, astute politicians recognized the importance of the immigrant vote. Jefferson and his followers labored hard and successfully to capture the loyalties of the newcomers. No single factor did as much to destroy the Federalists as a political party as the hostility of its hard-core Yankee group to the newer immigrants. Only a few Federalists realized that survival as a major party depended upon drawing a circle ever larger to include new and diverse groups, that American politics must be coalition politics. Too late did Alexander Hamilton and others recognize the political impotence of the policy of exclusion responsible for the Alien and Sedition Acts. In a last ditch effort to capitalize on the growing number of immigrant voters, the Federalists of New York offered a sprightly campaign tune for the gubernatorial election of 18 ro:

Come Dutch and Yankee, Irish, Scot,

With intermixed relation;

From whence we came, it matters not;

We all make, now, one nation.

\footnotetext{
A.B. 1950, New York University; Ph.D. 1955, Harvard University. Assistant Professor of Political Science, Brandeis University. Author, The Polmtical Behavior of American Jews (1956). Contributor to political science periodicals.

${ }^{2}$ Throughout this article, the writer has relied heavily on data compiled by the Bureau of the Census and on published election returns.
} 
But the basic animus of Federalist spokesmen, such as Harrison Gray Otis, of Massachusetts, and Uriah Tracy, of Connecticut, toward the same Dutch, Irish, and Scot celebrated in song was made clear in the Hartford Convention of $18 \times 2$. Blind to the realities of pluralistic politics to the last gasp, the Convention urged a constitutional amendment to bar naturalized citizens from elective and civil office.

\section{A. Scotch-Irish}

The Virginia Republicans who ruled the White House between 1800 and 1824 welcomed the support they received from the low-status immigrant groups. During the colonial period, Pennsylvania became the distribution center for one of the largest of these groups, the Scotch-Irish-Presbyterians. Not wanted by the Puritans of New England, they were driven to the frontier and, in turn, to democracy and a hatred of the British and Indians alike. These were natural recruits for a leveling party. For the first quarter of the nineteenth century (and beyond), the ScotchIrish played a leading role in the development of the Jeffersonian Party, feeding it with votes and leaders, some of whom reached the White House (Jackson, Polk, Buchanan).

\section{B. Irish-Catholics}

Soon replacing the Scotch-Irish-Presbyterians as the core ethnic group of the Democratic Party were Irish-Catholic immigrants. No other group has shown the flair and skill and group cohesiveness which, for more than a century, has characterized the political behavior of Irish-Americans.

Between I820 and 1920, over four and one-half million Irish immigrants came to the United States, the great bulk arriving between 1840 and $x 890$. The summer of 1845 was the first of a series of cold and damp Irish summers which caused onefourth of the Irish countryside to succumb to disease. Nearly one million Irish immigrants arrived between $185 \mathrm{I}$ and $\mathrm{I} 860$. These became the unskilled, marginal workers of America. Lacking the means to go West, most of them supplied the brawn so desperately needed in the industrial East. They worked in construction gangs, building aqueducts, canals, and railroads, and they worked in the mines and mills. The party of Jackson was congenial to their aspirations for a better ilfe, and the political talents of the Irish were welcomed by it.

The customary explanation for the Irish genius in politics rests on the Irish bent for oratory, his entrepreneural aptitude, and his conviviality. Without denying any of these, a sounder interpretation would insist on the following primary factors: the majority of Irish immigrants came within a forty-year period when naturalization was easy and when routes to prestige and privilege outside of politics were closed to them. They had one commodity of high value-votes! In the run-down rookeries and shanty-towns where they dwelled, their needs were great. A bargain was struck. For the votes of large Irish families, their own political leaders would minister to the sick and weary, get a few jobs, and buy some drinks. Irish political 
power lay in the deliverability of the Irish-Democratic vote. The Irish, who fought free Negro labor on the docks of New York, had no sympathy for abolition and the new political parties which promoted the cause of the Negro. Alone among the large ethnic groups, they clung to their Democratic moorings after the war. Inevitably, they rose to key positions of leadership and skillfully recruited the newer immigrant groups into the Democratic Party. They also had the singular advantages of speaking English, being familiar with the mechanics of government, and being here first. For a half century after Appomattox, the Irish kept the Democratic Party alive.

\section{Germans}

German immigrants also made a unique contribution to the shaping of our party system. Nineteenth-century German political behavior must be broken into two periods. Before 1850 , the vast majority of Germans appear to have been Democrats. The slavery issue plus the sudden rush of German immigration in the 1850 's, however, brought about a new and significant alignment. The Kansas-Nebraska Act of ${ }^{8} 8_{54}$ turned many Germans from the Democrats and Douglas. German immigrants were drawn in ever larger numbers to the new parties of free soil and free men.

Between 1845 and the outbreak of the Civil War, I,250,000 German refugees came to America. Many remained in New York City, perhaps ro0,000 in all. Most of them, however, migrated westward, along the Erie Canal, to the Great Lakes, and on to the prairies. Cincinnati became a leading German-American city. Columbus, Cleveland, Dayton, and Toledo in Ohio developed sizable German communities. Hundreds of thousands settled on farms. By 1860 , there were more than $130,000 \mathrm{Ger}-$ mans in Illinois. To Wisconsin, particularly in the eastern and northcentral counties, came thousands of German homesteaders. For one hundred years, GermanAmericans living in the Midwest have constituted one of the most vital ethnic core groups in the Republican Party.

One important factor, however, mitigated the attraction of the Republican Party for German immigrants. Nativist Whig elements in some areas were instrumental in the formation of the new party. When an amendment to the Massachusetts Constitution was voted which would deprive all citizens who had not been naturalized for more than two years of the right to hold office, German-Americans made the Massachusetts amendment a national issue. Republicans generally were blamed, although the Know-Nothing Party, in control in Massachusetts since 1855, was actually responsible for pushing the amendment through. Lincoln was forced to reply to German charges of nativism. Chase and Seward were obliged to reassure Germans publicly. Republican leaders intensified their efforts to woo Germans. Local prohibition laws were amended to permit the sale of cider, beer, and cheap wines. Promises of patronage and cheap land were made. State Republican Parties nominated Germans for office, and in the national convention in 1860, German- 
Americans won a plank which came out squarely against the Massachusetts amendment or any other curtailment of the rights of naturalized citizens. Lincoln, after the election, then drew his German followers closer to the party through a liberal use of patronage. Finally, Republican homestead, reconstruction, monetary, and civil service policies appealed to the rugged virtues of German agrarian Protestantism. The biggest German migrations were yet to come, and the arrival of $1,452,970$ German immigrants between $\mathrm{r} 88 \mathrm{r}$ and $\mathrm{I} 890$ probably assured Republican domination of national politics from 1896 to 1930 as much as any other single factor.

\section{Scandinavians}

The last of the great nineteenth-century immigrant groups were the Scandinavians. The Norwegians and Swedes were largest among these. Their role in shaping the American party system parallels that of the Germans, although quantitatively it is not nearly as important. In 1850 , the federal census revealed only 12,678 Norwegians in the United States. Twenty years later, the number had jumped to II4,243. By I872, they were concentrated in southeastern Wisconsin, with lesser numbers in Chicago, northern Illinois, central Wisconsin, southeastern Minnesota, and northeastern Iowa.

Altogether, about two million Scandinavians arrived between 1820 and I920, climaxed during the I880's, when in I882, roo,000 settlers arrived. To this day, Swedes are an important political group in Minnesota, Iowa, Michigan, Illinois, Nebraska, the Dakotas, and Wisconsin. Probably four-fifths of the Swedish immigrants settled on the land, where their descendants live today.

Earliest Norwegian immigrants tended to vote for Democratic or Free Soil candidates before the Civil War. Whigs were suspect because of snobbishness and nativism. Like the Germans, the swelling Scandinavian population moved into the Republican Party with ease in the years following the war. Like the Germans, they opposed slavery, wanted free homesteads, and were sedulously cultivated by Republican politicians. Between 1860 and 1873 , seventeen Norwegian-American newspapers were born (under different auspices), and all but one supported Republican policies. $^{2}$

\section{II}

\section{New Immigrants Versus the Old}

Scotch-Irish, Irish-Catholics, Germans, and Scandinavians-these were the four key ethnic groups in nineteenth-century American politics, each forming a stable element in the long-run development of one of our major parties. In their day, they were all new immigrant groups, and all suffered discrimination at the hands of Yankees already here.

The mutual hostility of old and new immigrant groups has been a persistent

${ }^{2}$ See Anlow W. Andersen, The Immigrant Takes His Stand i2-I3 (I953). 
theme in American life and politics. It has given rise to the formation of new political parties, such as the American and Know-Nothing Parties in the midnineteenth century. It has shaped the politics of entire regions, such as Rhode Island and Massachusetts, where political battle between Republicans and Democrats is partially the formal expression of deeper conflicts between Yankee-Protestants and Irish-Catholics. ${ }^{3}$ Clashes between old and new immigrant groups often show themselves in a struggle for local political power. One hundred years ago, the Yankees in New York City fought a losing battle to keep newcomer Irishmen from gaining the upper hand. Today, the Irish defend their political bastions against the mounting onslaughts of Italians and, to a lesser extent, Jews and Negroes.

\section{III}

\section{Nattisism in American Politics}

Nativism-the fear of and hostility toward new immigrant groups-has been sharply etched in the tradition of American politics. There have been four broad nativist phases. Originally, nativism was simply the antagonism of old immigrants for new. With the arrival of large-scale Irish-Catholic immigration, it became primarily anti-Catholic, not just antiforeign. Thus, it became possible for the Germans and Swedes, once recovered from the wounds inflicted by initial struggles with Yankees, to join their former Protestant foes in shaping the nativist pattern. The third phase of American nativism came in response to the twentieth-century migrations of Italians, Jews, and East Europeans, combined with the growth of the cities. This third phase was not just anti-Catholic, anti-Semitic, or even antiforeign; it was largely antiurban. The Irish, although by this time an old immigrant group, could not yet become a part of the nativist tradition because they were too closely identified with the newer immigrants. They not only had failed to achieve economic status, they also were Catholic, lived in the big cities, and, indeed, were the organizers of the new immigrant voting power. It is only in the fourth phase of American nativism-the anti-Communist phase-that the Irish begin to swim in the main stream of American nativism.

The most crucial phase of American nativism is the second one-the reaction to Irish-Catholicism. This is the phase which cut most deeply and affected the largest number of people. It is the only phase which brought forth a major political partythe Know-Nothing movement of the 1850 's. By 1830 , there were 150,000 IrishCatholics in New York alone. Small nativist parties emerged there and elsewhere. They flourished independently in the North and South and produced newspapers in a dozen cities. Riots, bloodshed, and the burning of churches were common in New

\footnotetext{
${ }^{3}$ There exists in Massachusets an almost perfect correlation between the Yankce-ness and Republican-ness of counties, regardless of their wealth. For example, the three most Protestant counties, Barnstable, Nantucket, and Dukes, are the most Republican countics, even though they are among the poorest in the state as measured by census figures for the median income of families and unrelated individuals.
} 
York and Philadelphia. Presidential politics were affected. Van Buren was accused of being a Catholic in the 1836 campaign, and Polk was attacked on the floor of Congress for pandering to the Catholic vote in 1844 . When it appeared that the foreign vote was responsible for Polk's election, membership in nativist parties rose sharply. In I845 and I847, national conventions of the Native-American Party were held.

Probably more attention was paid to the foreign vote in 1852 than ever before in a presidential election. A nation-wide outbreak of antiforeignism and antiCatholicism was occasioned by the election of Franklin Pierce. The result was the Know-Nothing Party. No political party in American history ever achieved the status of a major party so swiftly. No other party ever fell so fast. The platform of the party was simple. Members were pledged to vote for native-born candidates, to work for a long period of probation before naturalization, and to oppose the Catholic Church.

Within five years after its organization in New York in 1850 , every state and territory in the country had a Know-Nothing executive council. In Connecticut, the Know-Nothings absorbed the Whig remnants. In I854, Know-Nothing governors were elected in Massachusetts and Pennsylvania. Every member of the Massachusetts Senate and 375 of the 379 representatives were Know-Nothings. ${ }^{4}$ In 1855, the party elected governors in Rhode Island, Connecticut, New Hampshire, California, and Kentucky. Five state legislatures were captured, and as many as one hundred congressmen-elect shared the Know-Nothing point of view. In the South, where the Know-Nothings took over what was left of the Whig Party, substantial victories were won in $185^{6}$ in Kentucky, Tennessee, and Louisiana. Millard Fillmore, the Know-Nothing candidate for President, received 874,534 votes, more than half from the South.

Within a year, however, the Know-Nothing Party was destroyed. It foundered on the slavery issue. To please its northern faction, it condemned the Kansas-Nebraska Act in its national platform of 1856 . To placate southern elements, it demanded enforcement of the Fugitive Slave Act. Neither side would be mollified.

The deposit left by this second phase of American nativism has been very large, and has located in a variety of political and social movements. The American Protective Association, born in Clinton, Iowa, in 1887 , was founded almost entirely on anti-Catholicism, having its greatest impact in the Protestant Bible belt. Reaching its peak in 1894 , it claimed one million members, one hundred of whom were elected to the 54th Congress. Populist and Prohibition Party platforms absorbed much of the APA nativist program in 1892 , but the issue of nativism was again obscured by larger questions-free silver and Bryanism.

A resurgence of nativism followed World War $I$. The new nativism was antiurban and anti-Semitic as well as anti-Catholic and flowered in the Ku Klux Klan,

\footnotetext{
- See John Carroli noonan, Nattuism in Connecticut, r829-1860, at igi (1938).
} 
which, by r 925 , had five million members in strongholds throughout the South and in Ohio and Indiana. Again, a deeper and more pervasive issue came along-the depression-to cut across and veil the nativist battle.

\section{IV}

\section{Twentiethi-Century Immigration and American Politics}

Four-fifths of the southern and eastern European immigration which came after r880 stopped within the great urban triangle formed by St. Louis, Washington, and Boston, much of it remaining in New York City. The new immigrants went to the cities not so much because they were urban folk-many Jews from the villages of East Europe were not, nor were many Italians and Greeks-but because their own economic needs and the demands of industrialism made it so. The free homesteads were gone. Three and one-half million came from Poland and stayed; two and three-quarter million from Russia; four and one-half million from Italy.

The arrival of new migrations coupled with the increasing involvement of the United States in foreign affairs were responsible for the intensification of ethnicgroup politics in the twentieth century and for the burgeoning of a fourth phase of American nativism.

Rarely, in the nineteenth century, did foreign policy issues play havoc with the stable party loyalties of our large ethnic groups. The Irish were tried by Cleveland's alleged friendship for Great Britain, and Republican inroads were made on the Irish vote in 1888 . But the dominant issues in American politics between 1845 and the end of the century were domestic. Only since World War I have foreign policy issues disrupted the long-term party alignments of major ethnic groups.

Both World Wars were opposed by the Germans and the Irish. The seventy. year-old German association with the Republican Party was almost interrupted by the Igr6 slogan, "He kept us out of war." But German-Americans recoiled from the Democratic Party once Wilson took us into battle against the fatherland. They bounced back slightly with the disappearance of foreign policy issues in the I932 and 1936 campaigns, when poor and middle-income farmers, regardless of ethnic background, were drawn to the agricultural programs of the New Deal. With the emergence of foreign issues again in the late thirties, however, the Republican tendencies of German voters were intensified, a posture they maintained, with a somewhat larger number of exceptions than usual in 1948, through 1952.

Irish-Americans were no less hostile to Wilson's English war and the Versailles Treaty which followed than were the Germans. However, the virtual absence of foreign policy issues for fifteen years following the r920 election (it still made good sense for mayoralty candidates in Irish cities to run against the King of England and the World Court) made it possible for the Irish comfortably to remain good Democrats. With the advent of World War II, Irish support for Roosevelt fell off sharply, as a close look at Irish districts in the r 940 and 1944 election shows. 
The hard core of American isolationism during the thirties and early forties came from German-Republicans and Irish-Democrats. With the ending of the war and the rise of the Stalinist menace, however, Irish-Catholics could no longer maintain an isolationist position. Isolationism was transformed into nationalism and revisionism. The latter meant repudiating the Wilson and Roosevelt policies of aiding Britain against Germany. It also meant placing the blame for mistakes in World War II and the success of post-war Communism. The new nationalism meant Asia first, repudiation of the UN, and talking tough with Moscow and our allies. To these appeals, the Irish were congenial. But these very appeals were weapons in the arsenal of Republican leaders-McCarthy, Nixon, Knowland-and were used successfully in the 1952 campaign to split the Irish vote as it has never been split before.

It is this new turn in American politics that has finally allowed the Irish to participate in the tradition of American nativism. The first nativist phase was directed against them because they were new. The second hit them because they were Catholic. They were on the receiving end in the third phase because they were identified with the twentieth-century immigrant groups. Only now that Americanism has been mistaken for anti-Communism do the Irish march in the nativist pattern. The Know-Nothingism of the I950's, so closely associated with the names of two Irish-Catholics, McCarthy and McCarran, feeds on the American fear of foreign domination no less than anti-Catholic persecutions thrived on hallucinations of Papal rule or than the Alien and Sedition Acts of 1798 and the waves of antiBolshevik terror which followed World War I were born in fright of foreign dangers.

\section{V}

\section{The Pluralism of Amierican Politics}

Negro rights issues, ethnic-religious group clashes, and class divisions have all formed the bases of party alignments in American political history. Not all three come to the fore at the same time or with the same intensity. Often they cut across each other. Class conflict (in a Marxian sense) dominated colonial politics (e.g., Paxton's Boys, Bacon's Rebellion, and Shays's Rebellion) because of the relative religious and ethnic homogeneity of the population and because slavery was not yet a significant social factor. During and prior to the Jacksonian period, class and ethnic cleavages combined to yield status politics (e.g., the Whiskey Rebellion was sometimes called "The Scotch-Irish Rebellion"). In the years preceding the Civil War, sectional division based on the slavery struggle and ethno-religious conflict based on the nativist crusade moulded American party alignments. From Appomattox until World War I, domestic issues dominated the party battle; with some exceptions, class politics prevailed (e.g., the Haymarket riots, Populism, and Bryan's Cross of Gold Speech). During the late twenties and the early thirties, it was 
status politics again; the upward thrust for status of the sons and daughters of the twentieth-century immigration combined with the economic drives of low- and middle-income groups generally to make the Democratic Party the majority party for the first time in eighty years.

Following the end of large-scale immigration and the quiescence of Negro rights issues in the early thirties, the further development of class politics was often prophesied. The rapid urbanization of American society, it was predicted, would obliterate sectional politics based on a region's dominant crop, and would, by nationalizing domestic issues, cause the relationship of a voter's position in the economic system to govern his political behavior. The assimilation of the last of the immigrants would speed the process.

The prophets have tended to be correct only in those elections in which foreign policy issues were of minor importance. In 1932 and 1936 , there was a sharp division between income classes in the distribution of the presidential vote. ${ }^{5}$ In 1948 , when most voters outside of the South were concerned about domestic economic questions, and when "foreign policy played no great part in voters' thinking about the election," there were much greater differences in Democratic and Republican strength between income and occupational class groups than in 1940 and 1944.

In the early forties, foreign policy issues-questions of war and peace-were important to the voters. In those years, the interests of various large ethno-religious groups wrecked any theory of class politics. Then, the prosperous voters of the nation were much closer to the poorest electors in their presidential preferences, because, for a simple example, many wealthy Jews (the Jews were 92 per cent Democratic) and Poles voted Democratic, while many poor Italians and Germans voted Republican. In 1948, the lower-income groups were much more Democratic than they had been in the previous election, ${ }^{7}$ because the great issue of intervention versus isolation had been taken out of the political arena. Low-income Irishmen, who in x944 felt obliged to express their dissatisfaction with the prolonged and enervating war they judged to be England's, in I948 could go back to voting their pocketbooks.

By 1952 , the bipartisan foreign policy had disintegrated. Foreign policy issues again dominated the presidential campaign. Ethno-religious feeling, dormant in

"See Ogburn and Hill, Income Classes and the Roosevelt Vote in 1932, 50 Pot. Scr. Q. 186 (1935). Ogburn and Hill limited this study to a correlation of the vote with rental levels in 40 Illinois citics, including Chicago. Also see Ogburn and Coombs, The Economic Factor in the Roosevelt Elections, 34 AM. Pol. Sci. Rev. 719 (x940).

- Angus Campbell and Robert L. Kahn, The People Elect a President 57 (I952).

${ }^{7}$ See Elmo Roper, N. Y. Herald Tribune, June 19, 1949, p. 19, col. 4. Roper reported the figures for Boston, which he said were typical:

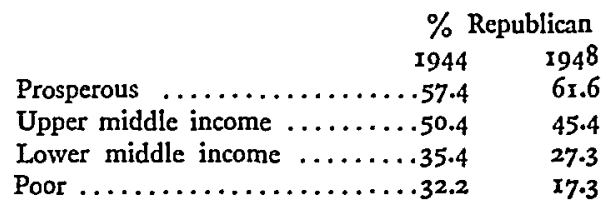


I948, rose to a considerable temperature in I952. Again, the gap in Democratic or Republican strength between the high-and low-income and occupational-prestige groups was closed. ${ }^{8}$ For example, the difference in the percentage Republican vote between the professional and managerial groups, on one hand, and the skilled and semiskilled workers, on the other, was narrowed from $5^{8}$ per cent in $194^{8}$ to merely 25 per cent in 1952 . The Polish lathe operator who knew his economic interests when he saw them in I948 did not find the Taft-Hartley issue so compelling when he had a chance to punish the perpetrators of Yalta in 1952. The Irish-Catholic milkman who thought well of Harry Truman in I948 could not forgive him four years later for his stubbornness in sticking with Secretary of State Acheson. The German wheat farmer who thought it better to vote for certain fixed prices under Truman than to gamble with Dewey in 1952 welcomed the chance to vote for a man who seemed to promise full parity and, at the same time, freely indulged in criticism of past Democratic foreign policies.

The urbanization of American society has not produced class politics mainly because America has been moving out into the rest of the world even more quickly than farmers have been moving to the city. And the hopes and fears of many of our ethnic groups soar in elections when foreign policy issues are at stake.

Two world wars and the menace of world Communism have intensified nationality and ethnic group cleavage as a basis for party division. What do these developments portend for changing party alignments? Incipient ethnic realignments were already noticed in 1952, when Irish-Catholic and Polish-Catholic voters switched more sharply from their Democratic affiliation than any other group. ${ }^{9}$

It has long been supposed, and, indeed, is still generally believed that the Republicans are more deeply divided on foreign policy issues than the Democrats. The reason for that belief is that for nearly one hundred years, the core ethnic groups in the Republican Party have been rural Yankees and rural Germans and Scandinavians. While the Yankees have generally endorsed participation in both world wars and in international organizations, the German and Swedes have not.

What has only recently been noticed is that the Democratic rank and file (party voters as distinguished from party leaders) have also been deeply divided on foreign policy issues. The Irish pull in one direction; the Jews, Italians (except in I940), and Poles (until Yalta) pull in another.

The Republicans give the impression of greater division because German and Scandinavian voting strength is disproportionately represented by Senators from the Midwest (Bricker, Case, Dirksen, Hickenlooper, Langer, Martin, McCarthy, Mundt, Jenner, Schoeppel, Young, and Thye) and in the House by representatives from districts gerrymandered to favor rural (German-Scandinavian) voting strength. Irish

\footnotetext{
${ }^{8}$ See Campbell, Curin, and Miller, The Elector Switch in 1952, Scientific American, May 1954, 0. 34.

- Survey results show that although twice as many Catholics voted Democratic as voted Republican in 1948 , Catholic voters split evenly in 1952. See Angus Campbell, Geraid Curin, and Warren E. Miller, The Voter Decides 7I (I954).
} 
voting power, on the other hand, is diluted in the big East Coast cities. ${ }^{10}$ The Irish have concentrated on the organizational aspects of politics. While they have contributed the last nine Democratic National Committee chairmen, they have not exercised power in formulating Democratic foreign policies since the Spanish Civil War. Many Yankees have played key roles in making Democratic foreign policies (Acheson, Hull, Hopkins, Lovett, Marshall, Stimson), however, and so have many Jews (Baruch, Cohen, Morgenthau, Rosenman); but not one Irish-Catholic.

The appearance of unity at the level of party leadership is deceptive, however; the split at the level of the party rank and file is, nonetheless, great. That is why Democratic presidential candidates are now threatened when foreign policy issues dominate a campaign. Even if Eisenhower carries out the main outlines of the Truman-Acheson foreign policy, the Republicans are less threatened in presidential elections as long as they can continue to do three things: first, adopt a posture of toughness toward the Communists and our allies (e.g., unleash Chiang Kai-shek, agonizing reappraisal, massive retaliation); second, rake over the coals of past Democratic behavior (e.g., Yalta, Communism in government, the Korean War); and third, throw an occasional bone to nationalist-isolationist sentiment among Republican Senate leaders (e.g., discard the Genocide Convention and the International Bill of Human Rights, appoint men such as McLeod and Hollister to administer international programs, endorse a watered-down version of the Bricker amendment). These actions will help to wean Irish- and Polish-Catholics from the Democratic Party and will also serve to comfort the doubts of German and Scandinavian voters.

What turn ethnic group alignments will take in 1956 and in future elections depends on how foreign policy issues are debated. If the Democrats can succeed in keeping Yalta-type issues from dominating the campaign, they are likely to hold on to the Irish as a core ethnic group. If voters think Republican leaders are just as internationalist as the Democrats, and if domestic issues such as farm and labor problems primarily hold their attention, the Democrats will have a chance not only to gather the Irish closer to the bosom of the party, but to woo German and Scandinavian farmers along crop and class lines.

\section{VI}

\section{The Future of Ethno-Religrous Politics}

Although ethno-religious group interest still plays a crucial role in shaping the pluralistic character of American parties, present immigration legislation will, as the years go by, considerably lessen its influence. Already one important development has resulted, in part, from the closing of immigration-the extinction of the old-style political boss. A battery of social changes has emerged to revolutionize the

${ }^{10}$ Democratic Senators from the East Coast states, since the war, have been straightforward internationalists. Democratic Irish-Catholic isolationists cannot be elected from the large East Coast states. At least four have been defeated since $x 944$. Two internationalists were elected, however-the late Brian McMahon (Conn.) and John F. Kennedy (Mass.). 
social function of the boss. The curtailing of immigration is just one factorprosperity, education, the welfare state, population mobility, and mass media are others-but it is an important one. The last of the bosses-men who can deliver a bloc of immigrant votes for virtually any candidate-operate in areas which are most depressed and underprivileged. It is in the Negro, Mexican, Puerto Rican, and, to some extent, Italian neighborhoods where the old-style boss persists. The late Vito Marcantonio built his machine in the Puerto Rican slums of Manhattan's East Side. The recently dethroned George Parr, during the last twenty years, was able to deliver more than 90 per cent of the Mexican vote in Duval, Starr, and Webb Counties, Texas, to any candidate of his choice. But the Martin Lomosneys, Charles F. Murphys, and Frank Hagues are gone, if not forgotten.

Despite the disappearance of the immigrant, one aspect of ethno-religious politics that will undoubtedly survive for a long time concerns the political issues which divide our three great religious groups. While Protestant fundamentalists frown or gambling, many Jews and Catholics enjoy it. Bingo has recently been one of the hottest political issues in New York State. All members of the state Senate voting against its legalization were Republican Protestants. It is in the Protestant communities that the local option to enforce prohibition is exercised; never in Catholic towns and villages. Although Catholics and Jews are allied against many Protestants on gambling and liquor, it is the Protestants who join the Jews in opposing Catholics on the birth-control question.

The problem of the delicate relationship between Church and State usually finds Catholics at odds with Protestants and Jews. Two issues beginning to assume national significance are federal aid to education (including parochial schools) and the intrusion of religious teaching in public education. A bitter struggle developed in the 1954 election in New Jersey over the attempt of Governor Meyner to raise a twenty-five million dollar bond issue to build a state medical-dental school. Catholic authorities met the proposal as an attack on a projected medical school for Seton Hall, a Catholic university, and priests in Patterson and Passaic Counties successfully urged worshippers to vote against the measure when it was submitted to referendum.

Domestic political issues which divide our three major religious groups are not new. The point is that they will not disappear with the cessation of immigration and will not evaporate in the foreseeable future. But the impact of such issues on national politics, with the exception of presidential elections in 1884 and 1928 , has been slight. Under the federal system, issues which divide the religious groups will remain primarily local.

A major question still remains. How will the changing ethnic composition of our population affect major party alignments? We are still in a period when the shifting demography of our foreign-stock groups favors the Democrats, at least as alignments now stand. The total number of the foreign-stock ${ }^{11}$ Italians, Poles,

${ }^{21}$ Foreign-stock meane born abroad or one or more parent born abroad. 
Greeks, Jews, Austrians, and Hungarians (all more Democratic in presidential elections) is still going up, while the total number of foreign-stock Germans, Swedes, and Irish is steadily going down. But the proportion of total foreign-stock Americans goes down precipitously each year. The census for $195^{\circ}$ showed only 25.7 per cent of the white American population classified as foreign-stock compared to 30 per cent just twenty years ago.

The present McCarran-Walter Act favors immigration which will tend, if present group loyalties obtain, to help the Republicans, because so few immigrants are allowed to enter from southern and eastern Europe as compared to northern and western Europe. ${ }^{12}$ The evidence is overwhelming that recent English immigrants, Scandinavians, and non-Jewish Germans tend to adopt the Republican affiliations of the high-status ethnic groups to which they belong.

The Democrats will fare only slightly better from emergency immigration legislation under current party alignments. Nonquota immigrants admitted in 1954 totaled Ir4,079. Of these, 34,456 were Mexican, 27,055 Canadian, 19,309 English, 15,50r Italian, and 42,935 German. The Mexicans were largely seasonal labor brought in to offset labor shortages in the Southwest. Of those Mexicans, FrenchCanadians, and Italians who remain in the United States and become voting citizens (perhaps as little as one-third), a large majority will become Democrats as long as present alignments continue. A large number of immigrants from Germany are actually refugees from East European Communism arriving under the Refugee Relief Act of $1953 .^{13}$ Should, as may be expected, Yalta-type politics disappear, a large number of these will vote tor Democratic candidates eight and twelve years from now.

The total number of immigrants-208,17r in 1954-admitted under all current legislation is too small, however, to make much impact on the future of American politics. Some stimulation to ethnic- and nationality-group politics will result from the admission of Alaska and Hawaii as states. The total number of foreign-stock Asians is up to 350,000 . To a very large extent, Japanese-Americans (the largest of the Asian groups) have been apolitical, ${ }^{14}$ but the admission of Hawaii, where JapaneseAmericans now constitute the core ethnic group of the Democratic Party, is likely to have a sharp effect on the voting habits of Japanese on the continent. In California, where 100,000 of them live, Japanese may become a pivotal force in politics. Asian-American involvement in American politics will grow rather than lessen as the Asian population expands and as the United States becomes more involved in far eastern affairs.

Two other potential sources of ethnic-group influence in politics remain to be

12 Under the act, 154,657 aliens are permitted to enter each year: 125,165 from northern and western Europe, the rest from southern and eastern Europe. Proclamation No. 2980, 66 STAT. c. 36, 8 U.S.C. $\$$ II51 (1952). Actually, 63,649 northern and western Europeaps were admitted in 1953, as compared with 18,582 southern and castern Europeans.

${ }^{13} 67$ STAT. 400, 50 App. U.S.C. \$ I97I (Supp. I955).

isee Forrest E. LaVioletts, Americans of Japanese Ancestrx (unpublished Ph.D. thesis in University of Chicago Library 1946). 
discussed. Legal Puerto Rican migrations and illegal Mexican entrants now constitute two of the largest groups of newcomers to the United States. In I953, 63,000 Puerto-Ricans entered the United States. The number has been halved in the past two years, and some experts predict that migration will dwindle to a trickle by I960. Nonetheless, Puerto-Rican Americans will be a sizable voting group within a decade and predominantly Democratic. Their influence will be local, however, especially in New York, since foreign policy will not involve them as a group. Mexican-Americans will also form an important local political force (Los Angeles is 16.5 per cent Mexican), but will not be influential in national politics.

Only a fundamental liberalization of our immigration laws will sustain the contribution which ethno-religious group interests have made in shaping the American party system. ${ }^{15}$ Liberalization is, in the immediate future, highly unlikely. The executive branch of the national government has consistently proposed the easing of our immigration statutes in recent years, but the Congress has just as consistently rebuffed it. The reason is that urban constituencies, by virtue of the fact that the president must win in the large urban states to prevail in the electoral college, can bring considerable pressure to bear on presidential candidates; but in Congress, urban voters are heavily discriminated against by overrepresentation of rural state: in the Senate, and by gerrymandering and the seniority rule in the House.

Immigration policy is determined primarily by Congress, which is not as susceptible to pressure or blandishments from the executive in this matter as it sometimes is on critical foreign policy or financial legislation. The rural constituencies, so heavily overrepresented in Congress, comprise the old immigrant groups which oppose liberal immigration-Yankees, Germans, and Scandinavians in the rural Midwest, Yankees in rural New England, and Anglo-Saxons in the South. These are the groups which developed and nourished the tradition of nativism. Now they have been joined by the Irish. Only the Italians, Poles, and Jews, among the numerically important ethnic groups, support proposals for liberal immigration These groups must be pandered to by presidential candidates, but they wield little influence in Congress.

Only reform of Congress (the end of gerrymandering by state legislatures and an end to seniority) coupled with constitutional reform (elect members of the House every four years concurrently with the president) might possibly get proposals for drastic revision of our restrictive immigration statutes through the House of Representatives. Since neither of these reforms is likely, the prospects appear to be dim.

Politics in America will be pluralistic for a long time. There are many factors working against class politics in addition to ethno-religious diversity. But differences in ethnic-group interests will not, given present immigration legislation, play the large role in forming national party alignments in the last half of this century that they have in the past.

\footnotetext{
${ }^{16}$ Whether that contribution has been a good or bad thing is not under consideration here. The normative aspects of the problem are discussed in the first chapter of the writer's book, The Political Behavior of American lews.
} 